\title{
INACTIVATION OF MACROPHAGE NITRIC OXIDE SYNTHASE ACTIVITY BY $\mathrm{N}^{\mathrm{G}}$-METHYL-L-ARGININE
}

\author{
Norman M. Olken§, Kristin M. RuscheI, Michael K. RichardsI, and Michael A. Marletta\$ף*
}

Interdepartmental Program in Medicinal Chemistry§, College of Pharmacy and the Department of Biological Chemistryll, School of Medicine, University of Michigan, Ann Arbor, MI 48109-1065

Received April 26, 1991

Summary. $\cdot \mathrm{N}=\mathrm{O}$ synthase catalyzes the oxidation of one of the two chemically equivalent guanido nitrogens of L-arginine to nitric oxide $(\cdot \mathrm{N}=\mathrm{O})$. $\mathrm{N}^{\mathrm{G}}$-Methyl-L-arginine has been previously characterized as a potent competitive inhibitor of both major types of $\cdot \mathrm{N}=\mathrm{O}$ synthases. Initial rate kinetics were performed with a spectrophotometric assay based on the oxidation of oxy- to methemoglobin by $\cdot \mathrm{N}=\mathrm{O}$. $\mathrm{N}^{\mathrm{G}}$-Methyl-L-arginine was a competitive inhibitor of $\cdot \mathrm{N}=\mathrm{O}$ synthase activity derived from activated murine macrophages with a $\mathrm{K}_{\mathrm{i}}$ of $6.2 \mu \mathrm{M}$. When the enzyme was pre-incubated in the presence of the required cofactors NADPH and tetrahydrobiopterin, time- and concentration-dependent irreversible inactivation of the activity was observed. At $37^{\circ} \mathrm{C}$ the $\mathrm{k}_{\text {inact }}$ was $0.050 \mathrm{~min}^{-1}$. This inactivation process exhibited substrate protection, saturation kinetics and required the cofactors necessary for enzymatic turnover. These data indicate that $\mathrm{N}^{\mathrm{G}}$-methyl-Larginine acts as a mechanism-based enzyme inactivator of murine macrophage $\cdot \mathrm{N}=\mathrm{O}$ synthase.

(6) 1991 Academic Press, Inc.

Many cells are now known to synthesize nitric oxide $(\mathrm{N}=\mathrm{O})$ by the oxidation of one the two chemically equivalent guanido nitrogens of L-arginine (1). Two types of $\cdot \mathrm{N}=\mathrm{O}$ synthases have been identified: a constitutively expressed $\mathrm{Ca}^{2+} /$ calmodulin-dependent form isolated from rat cerebella (2) and identified in vascular endothelial cells (3); and a cytokine inducible, calmodulinindependent form isolated from neutrophils (4) and macrophages (5), and identified in a wide variety of other cell types (6). Both forms of $\cdot \mathrm{N}=\mathrm{O}$ synthase utilize the co-substrates $\mathrm{L}$-arginine and molecular oxygen, and require NADPH. Tetrahydrobiopterin $\left(\mathrm{BH}_{4}\right)$ has been shown to be a required cofactor for $\cdot \mathrm{N}=\mathrm{O}$ synthase activity derived from the supernatant of activated murine macrophages $(7,8)$.

The inducible form of $\cdot \mathrm{N}=\mathrm{O}$ synthase isolated from macrophages and neutrophils is expressed in response to various cytokines, such as interferon- $\gamma$, tumor necrosis factor- $\alpha$ and bacterial lipopolysaccharide. Upon induction, these cells generate $\cdot \mathrm{N}=\mathrm{O}$ continuously for as long as

* Address correspondence to this author at College of Pharmacy, 428 Church Street, University of Michigan, Ann Arbor, MI 48109-1065.

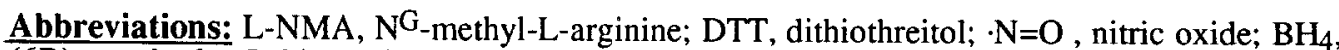
(6R)-tetrahydro-L-biopterin; $\mathrm{BH}_{2}, 7,8$-dihydro-L-biopterin; NADPH, nicotinamide adenine dinucleotide reduced form; NADP ${ }^{+}$, nicotinamide adenine dinucleotide oxidized form; HEPES, 4(2-hydroxyethyl)-1-piperazineethane sulfonic acid; oxyHb, ferrous oxyhemoglobin; metHb, ferric hemoglobin.
} 
72 hours (9). This $\cdot \mathrm{N}=\mathrm{O}$ clearly serves to augment cell-mediated immunity. Specifically, $\cdot \mathrm{N}=\mathrm{O}$ has been shown to cause a pronounced loss of intracellular iron and the inhibition of the iron-sulfur protein aconitase in $\mathrm{L} 10$ hepatoma cells $(10)$. The iron-sulfur protein ribonucleotide reductase also appears to be an important target for $\cdot \mathrm{N}=\mathrm{O}(11)$. Additionally, the intracellular destruction of Leshmania (12) and Toxoplasma gondii (13) by macrophages has been closely correlated with $\cdot \mathrm{N}=\mathrm{O}$ generation.

$\mathrm{N}^{\mathrm{G}}$-Methyl-L-arginine (L-NMA) was initially reported by Hibbs and colleagues to be a potent inhibitor of macrophage nitrite generation (14). In fact, L-NMA has been reported to be a competitive inhibitor of both forms of the $\mathrm{N}=\mathrm{O}$ synthase $(15,16)$. We noted a time-dependent loss of $\cdot \mathrm{N}=\mathrm{O}$ synthase activity after pre-incubation with L-NMA, NADPH and $\mathrm{BH}_{4}$. This inactivation has now been characterized under initial rate conditions by measuring $\cdot \mathrm{N}=\mathrm{O}$ generation directly with a spectrophotometric assay based on the rapid and quantitative oxidation of oxy- to methemoglobin (metHb) by $\cdot \mathrm{N}=\mathrm{O}(17,18)$. L-NMA produces a time- and concentration-dependent irreversible loss of $\cdot \mathrm{N}=\mathrm{O}$ synthase activity from activated murine macrophages. This inactivation has all the markings of mechanism-based enzyme inactivation: turnover-dependence, saturation kinetics and substrate protection.

\section{Materials and Methods}

Analytical Methods. Assays for enzyme activity were carried out in disposable semimicro cuvettes (Bio-Rad), on a Perkin-Elmer 553 spectrophotometer equipped with a PerkinElmer R100 chart recorder. A reference cuvette was charged with $2 \mu \mathrm{M}$ oxyhemoglobin (oxyHb) in $15 \mathrm{mM}$ HEPES ( $\mathrm{pH} 7.4$ ), in a final volume of $500 \mu \mathrm{l}$. A typical sample assay contained $2 \mathrm{mM}$ L-arginine, $1 \mathrm{mM} \mathrm{Mg}{ }^{2+}, 167 \mu \mathrm{M}$ DTT, $100 \mu \mathrm{M} \mathrm{NADPH}, 12 \mu \mathrm{M} \mathrm{BH}_{4}$, and $2 \mu \mathrm{M}$ oxyHb in 15 mM HEPES (pH 7.4), in a final volume of $500 \mu \mathrm{l}$. All assays were initiated with protein. The HEPES buffer was heated to $37^{\circ} \mathrm{C}$ prior to use, and the cell holders inside the spectrophotometer were kept at $37^{\circ} \mathrm{C}$ with a Thermomix 1460 thermocirulator. Enzyme activity is directly proportional to the increase in absorbance at $401 \mathrm{~nm}$ over time. Protein concentration of desalted supernatant was determined with the Bradford Assay (Bio-Rad) using bovine serum albumin as the standard (19).

Reagents. NG-Methyl-L-arginine, acetate salt (L-NMA) was purchased from Calbiochem. L-arginine, human ferrous hemoglobin $A_{0}$, NADPH, DTT, HEPES, and magnesium acetate were purchased from Sigma. (6R)-5,6,7,8-Tetrahydro-L-biopterin $\left(\mathrm{BH}_{4}\right)$, and 7,8dihydro-L-biopterin $\left(\mathrm{BH}_{2}\right)$ were purchased from Dr. B. Schircks Laboratories, Jona, Switzerland.

Enzyme Preparation. Macrophage cytosol was prepared from the murine macrophage cell line RAW 264.7 and desalted as described previously (7). A typical preparation of desalted supernatent had a specific activity of $300 \mathrm{nmoles} \cdot \mathrm{N}=\mathrm{O} / \mathrm{mg}$ protein/hour as determined with the hemoglobin assay.

Competitive Inhibition of Murine Macrophage $\cdot \mathrm{N}=\mathbf{0}$ Synthase by L-NMA. Desalted supernatant $(60 \mu \mathrm{l})$ was added to an assay cuvette containing $50 \mu \mathrm{M}$ L-arginine, $1 \mathrm{mM}$ $\mathrm{Mg}^{2+}, 167 \mu \mathrm{M}$ DTT, $100 \mu \mathrm{M}$ NADPH, $12 \mu \mathrm{M} \mathrm{BH}_{4}, 2 \mu \mathrm{M}$ oxyHb, and $0,5,10,25$, or $50 \mu \mathrm{M}$ L-NMA in $15 \mathrm{mM}$ HEPES ( $\mathrm{pH} \mathrm{7.4)}$ ) at $37^{\circ} \mathrm{C}$, in a final volume of $500 \mu \mathrm{l}$.

Time- and Concentration-Dependent Inactivation of Murine Macrophage -N=O Synthase by L-NMA. Desalted supernatent $(300 \mu \mathrm{l})$ (typically about $500 \mu \mathrm{g}$ of protein) was added to a pre-incubation mixture to produce final concentrations of $1 \mathrm{mM} \mathrm{Mg}{ }^{2+}, 833 \mu \mathrm{M}$ DTT, $100 \mu \mathrm{M}$ NADPH, $60 \mu \mathrm{M} \mathrm{BH}_{4}$ and L-NMA in $15 \mathrm{mM}$ HEPES (pH 7.4), in a final volume of $600 \mu \mathrm{l}$. Concentrations of L-NMA in the pre-incubation mixture were $1.5,3.0,5,10,25$ or 50 $\mu \mathrm{M}$. After the addition of enzyme, an initial $100 \mu$ l aliquot was removed and assayed for activity as described below. The pre-incubation mixture was then placed in a $37^{\circ} \mathrm{C}$ water bath. Aliquots 
(typically $100 \mu \mathrm{l}$ ) were removed and assayed for activity after $15,30,45,60$ and 75 minutes. Each aliquot was added to a cuvette containing cofactors and oxyHb to produce a final volume of $500 \mu \mathrm{l}$ and final concentrations of $2 \mathrm{mM}$ L-arginine, $1 \mathrm{mM} \mathrm{Mg}^{2+}, 167 \mu \mathrm{M} \mathrm{DTT}, 100 \mu \mathrm{M}$ NADPH, $12 \mu \mathrm{M} \mathrm{BH}_{4}$, and $2 \mu \mathrm{M}$ oxyHb in $15 \mathrm{mM}$ HEPES (pH 7.4) at $37^{\circ} \mathrm{C}$.

Irreversibilty of $\cdot \mathbf{N}=\mathbf{O}$ Synthase Inactivation. A pre-incubation was performed at $37^{\circ} \mathrm{C}$ as described above in the presence of $25 \mu \mathrm{M}$ L-NMA for 45 minutes. At this time the remaining enzyme activity was measured, the pre-incubation was removed from the $37^{\circ} \mathrm{C}$ waterbath (the residual activity is unstable at $37^{\circ} \mathrm{C}$ ), placed at room temperature, and $5 \mathrm{mM} \mathrm{L}$ arginine was added. The activity was assayed at 30 minutes intervals for 2.5 hours, as described above.

Cofactor-Dependence of $\cdot \mathbf{N}=\mathbf{O}$ Synthase Inactivation. Pre-incubations and activity assays were run at $22^{\circ} \mathrm{C}$ in the presence of $25 \mu \mathrm{M} \mathrm{L}$-NMA, but otherwise as described above. $\mathrm{BH}_{2}$ and $\mathrm{NADP}^{+}$concentrations were 60 and $100 \mu \mathrm{M}$, respectively.

\section{Results}

Time- and Concentration-Dependent Inactivation of Murine Macrophage $\cdot N=O$ Synthase by $L-N M A$. Figure $1 \mathrm{~A}$ shows the time- and concentration-dependent inhibition of murine macrophage $\cdot \mathrm{N}=\mathrm{O}$ synthase by $1.5,5$ and $25 \mu \mathrm{M}$ L-NMA. The control experiment illustrates the relatively small loss in activity which occurs when the enzyme is pre-incubated with $1 \mathrm{mM} \mathrm{Mg}^{2+}$, $833 \mu \mathrm{M} \mathrm{DTT}, 100 \mu \mathrm{M} \mathrm{NADPH}$ and $60 \mu \mathrm{M} \mathrm{BH} 4$ in the absence of substrate. In the presence of Larginine, there is typically almost no loss of activity measured under these conditions after 1 hour (not shown). From a Kitz and Wilson replot (20) of $1 / \mathrm{k}_{\text {obs }}$ vs. $1 /[\mathrm{I}]$ (figure 2) a $\mathrm{k}_{\text {inact }}$ of 0.050 $\min ^{-1}$ and a $K_{I}$ of $4.2 \mu \mathrm{M}$ were obtained.
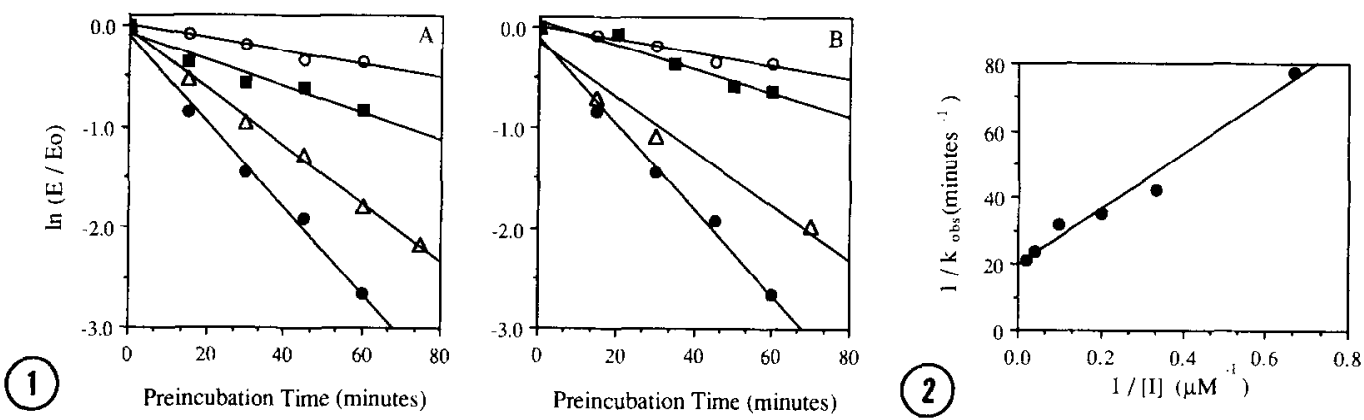

Figure 1A. Time- and Concentration-Dependent Inactivation of Murine Macrophage $\cdot \mathbf{N}=0$ Synthase hy $\mathbf{L}$-NMA. The vertical axis is the natural log of the ratio of enzyme activity remaining at the end of the pre-incubation time to the enzyme activity measured after no pre-incubation. All pre-incubations were done at $37^{\circ} \mathrm{C}$ with $0(0), 1.5(\boldsymbol{D}), 5(\Delta)$ or 25 (-) $\mu \mathrm{M}$ L-NMA, $1 \mathrm{mM} \mathrm{Mg}{ }^{2+}, 833 \mu \mathrm{M}$ DTT, $100 \mu \mathrm{M}$ NADPH, and $60 \mu \mathrm{M} \mathrm{BH}_{4}$. At 15 minute intervals the remaining activity was assayed as described in Methods.

Figure 1B. Concentration-Dependent Substrate Protection by L-Arginine. $\mathrm{L}$-arginine at $100(\Delta)$ or $500(\boldsymbol{D}) \mu \mathrm{M}$ concentrations was pre-incubated at $37^{\circ} \mathrm{C}$ with $25 \mu \mathrm{M} \mathrm{L}$ $\mathrm{NMA}$ and $1 \mathrm{mM} \mathrm{Mg} \mathrm{Mg}^{2+}, 833 \mu \mathrm{M}$ DTT, $100 \mu \mathrm{M}$ NADPH and $60 \mu \mathrm{M} \mathrm{BH}_{4}$. The control activity (O) represents a pre-incubation mixture of enzyme and $1 \mathrm{mM} \mathrm{Mg} \mathrm{Mg}^{2+}, 833 \mu \mathrm{M}$ DTT, $100 \mu \mathrm{M}$ NADPH and $60 \mu \mathrm{M} \mathrm{BH}_{4}$ without either substrate or inhibitor. Shown for comparison is a pre-incubation with $25 \mu \mathrm{M} \mathrm{L}-\mathrm{NMA}(\bullet)$ and no L-arginine run under the same conditions as above.

Figure 2. Kitz and Wilson Replot. The inactivation kinetics shown in figure 1A were replotted according to Kitz and Wilson (20). This graph includes the data from figure $1 \mathrm{~A}$ as well as that obtained from inactivation experiments with 3,10 and $50 \mu \mathrm{M} \mathrm{L}$-NMA (not shown). 


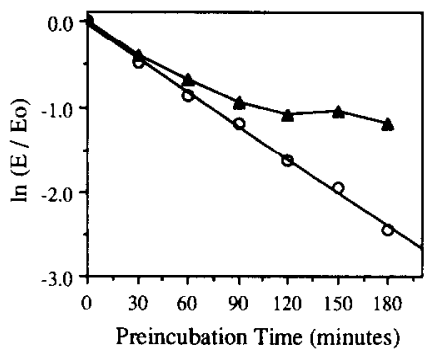

Figure 3. Cofactor-Dependence of $\cdot \mathrm{N}=\mathbf{O}$ Synthase Inactivation by L-NMA. Pre-incubation at $22^{\circ} \mathrm{C}$ with $25 \mu \mathrm{M}$ L-NMA in the presence of $1 \mathrm{mM} \mathrm{Mg}^{2+}, 833 \mu \mathrm{M}$ DTT, 100 $\mu \mathrm{M}$ NADPH and $60 \mu \mathrm{M} \mathrm{BH} 4(0)$ or $1 \mathrm{mM} \mathrm{Mg}^{2+}, 100 \mu \mathrm{M} \mathrm{NADP}+$ and $60 \mu \mathrm{M} \mathrm{BH} 2(\Delta)$. Each pre-incubation mixture also contained $300 \mu \mathrm{l}$ of protein in a final volume of $600 \mu \mathrm{l}$ of $15 \mathrm{mM}$ HEPES ( $\mathrm{pH} 7.4)$.

Irreversibilty and Saturability of $\cdot N=O$ Synthase Inactivation. Since enzyme activity was determined with a continuous spectrophotometric assay in the presence of $2 \mathrm{mM}$ L-arginine $\left(\mathrm{K}_{\mathrm{m}}\right.$ $7.4 \mu \mathrm{M}$ in this system), rapid reactivation of the $\cdot \mathrm{N}=\mathrm{O}$ synthase (following inactivation by $\mathrm{L}$ NMA) would have been apparent. However, even after 15-20 minutes of observation no evidence for any increase in the velocity of the enzymatic reaction was noted. In fact, no restoration of enzyme activity was detected when enzyme inactivated over 45 minutes by $25 \mu \mathrm{M}$ L-NMA was incubated at room temperature $\left(22^{\circ} \mathrm{C}\right)$ with $5 \mathrm{mM}$ L-arginine over 2.5 hours. The inactivation process was shown to be saturable as well, with concentrations of L-NMA greater than $25 \mu \mathrm{M}$ resulting in very small increases in the rate of enzyme inactivation (not shown).

Substrate Protection. Figure 1B shows the concentration-dependent substrate protection afforded by 100 and $500 \mu \mathrm{M}$ L-arginine when pre-incubated at $37^{\circ} \mathrm{C}$ with $1 \mathrm{mM} \mathrm{Mg}^{2+}, 833 \mu \mathrm{M}$ DTT, $100 \mu \mathrm{M} \mathrm{NADPH}, 60 \mu \mathrm{M} \mathrm{BH}_{4}$ and $25 \mu \mathrm{M}$ L-NMA.

Cofactor-Dependence of $\cdot N=O$ Synthase Inactivation. $\cdot \mathrm{N}=\mathrm{O}$ synthase activity requires NADPH (21), and, in fact, is quite unstable at $37^{\circ} \mathrm{C}$ in the absence of either NADPH or $\mathrm{BH}_{4}$. Therefore it was impossible to demonstrate the retention of enzyme activity following preincubation of the enzyme and L-NMA in the absence of one of these cofactors at $37^{\circ} \mathrm{C}$. At $4^{\circ} \mathrm{C}$ a pre-incubation with NADPI, $\mathrm{BH}_{4}$ and $25 \mu \mathrm{M}$ L-NMA showed no significant loss of activity over several hours (not shown). The problem of demonstrating cofactor-dependent loss of $\cdot \mathrm{N}=\mathrm{O}$ synthase activity with L-NMA was solved by pre-incubating the enzyme with reduced (NADPH and $\left.\mathrm{BH}_{4}\right)$ or oxidized $\left(\mathrm{NADP}^{+}\right.$and $\left.\mathrm{BH}_{4}\right)$ cofactors at room temperature $\left(22^{\circ} \mathrm{C}\right)$. Figure 3 shows the time-dependent loss of enzyme activity for a pre-incubation carried out at $22^{\circ} \mathrm{C}$ with $100 \mu \mathrm{M}$ NADPH, $60 \mu \mathrm{M} \mathrm{BH}_{4}$, and $25 \mu \mathrm{M} \mathrm{L-NMA}$. The $\mathrm{k}_{\mathrm{obs}}$ is $0.013 \mathrm{~min}^{-1}$, only $30 \%$ that observed at $37^{\circ} \mathrm{C}$.

A pre-incubation carried out at $22^{\circ} \mathrm{C}$ with the oxidized forms $(100 \mu \mathrm{M} \mathrm{NADP}+$ and $60 \mu \mathrm{M}$ $\mathrm{BH}_{2}$ ) of the required cofactors and $25 \mu \mathrm{M}$ L-NMA also initially demonstrates some enzyme inactivation, which slows after 30 minutes and ceases after about 90 minutes (Figure 3). Although some enzyme inactivation was evident when NADP+ and $\mathrm{BH}_{2}$ were used as cofactors, this may 
have been due to the in situ reduction of NADP+ to NADPH (7). Additionally, the pterin appears to be tightly bound (unpublished observations). For these reasons it was impossible to abolish enzymatic turnover. In fact, a low but detectable initial velocity of $\cdot \mathrm{N}=\mathrm{O}$ generation was noted with protein, oxidized cofactors, and L-arginine at $22^{\circ} \mathrm{C}$.

\section{Discussion}

In agreement with the initial observations, L-NMA was found to be a relatively potent competitive inhibitor of the $\cdot \mathrm{N}=\mathrm{O}$ synthase activity in activated murine macrophages. A $\mathrm{K}_{\mathrm{i}}$ of 6.2 $\mu \mathrm{M}$ was derived from a Dixon plot (not shown). For comparison, the $\mathrm{K}_{\mathrm{m}}$ of $\mathrm{L}$-arginine under these conditions was $7.4 \mu \mathrm{M}$. As described above and shown in figure $1 \mathrm{~A}$, pre-incubation of enzyme with L-NMA, NADPH, and $\mathrm{BH}_{4}$ at $37^{\circ} \mathrm{C}$ results in a time- and concentration-dependent loss of $\cdot \mathrm{N}=\mathrm{O}$ synthase activity. From a Kitz and Wilson replot (20) of $1 / \mathrm{k}_{\text {obs }} \mathrm{vs.} 1 /[\mathrm{I}]$ (figure 2 ) a $\mathrm{k}_{\text {inact }}$ of $0.050 \mathrm{~min}^{-1}$ and a $\mathrm{K}_{\mathrm{I}}$ of $4.2 \mu \mathrm{M}$ were obtained. In addition, as shown in figure $1 \mathrm{~B}$ the substrate $\mathrm{L}$-arginine protects against this inactivation in a concentration-dependent fashion suggesting that the inactivation process occurs at or near the active-site.

The inactivation of $\cdot \mathrm{N}=\mathrm{O}$ synthase is apparently irreversible. That is, enzyme inactivated during a 45 minutes pre-incubation by $25 \mu \mathrm{M} \mathrm{L}-\mathrm{NMA}$ was then incubated at room temperature with $5 \mathrm{mM} \mathrm{L}$-arginine for 2.5 hours. Aliquots removed at 30 minute intervals failed to demonstrate enzyme reactivation. The inactivation process was also shown to be saturable; concentrations of L-NMA greater than $25 \mu \mathrm{M}$ resulted in very small increases in the rate of enzyme inactivation (not shown).

The enzyme is unstable at $37^{\circ} \mathrm{C}$ in the absence of either $\mathrm{BH}_{4}$ or $\mathrm{NADPH}$, preventing the study of turnover-dependent inactivation at that temperature. Time-dependent inactivation of $\cdot \mathrm{N}=\mathrm{O}$ synthase activity also occurs at $22^{\circ} \mathrm{C}$ when the pre-incubation reaction contained NADPH, BH4, and $25 \mu \mathrm{M} \mathrm{L-NMA}$ (Figure 3). In contrast, also at $22^{\circ} \mathrm{C}$, a pre-incubation reaction which contained $\mathrm{NADP}^{+}, \mathrm{BH}_{2}$ and $25 \mu \mathrm{M} \mathrm{L}-\mathrm{NMA}$ did not demonstrate a time-dependent loss of $\cdot \mathrm{N}=\mathrm{O}$ synthase activity over 2.5 hours (Figure 3 ). In this way conditions were found which supported enzymatic turnover in the presence of the required reduced cofactors, and which maintained enzyme stability in their absence.

The inactivation of the enzyme most likely arises from one of three mechanisms (Scheme 1). One possibility is that L-NMA proceeds down the normal reaction pathway generating an $\mathrm{N}$-hydroxylated intermediate that is tightly bound. Thus, L-NMA could be converted to $\mathrm{N}^{\mathrm{G}}$-hydroxy- $\mathrm{N}^{\mathrm{G}}$-methyl-L-arginine, a mimic of $\mathrm{N}^{\mathrm{G}}, \mathrm{NG}_{\text {-dihydroxy-L-arginine, a }}$ proposed reaction intermediate (21). An alternative, covalent mechanism is the formation at the active site of a chemically reactive species such as a carbon-centered free radical or an imine-type Michael acceptor. Thirdly, peroxide formation uncoupled from substratc hydroxylation at the active site is a well-characterized means by which oxygenases like phenylalanine hydroxylase autoinactivate in the presence of some substrate analogs (22). We have synthesized [3 $\left.{ }^{3}\right]-\mathrm{L}-\mathrm{NMA}$ and are investigating the actual molecular nature of the inactivation by L-NMA herein reported. In addition, we are extending these findings to a number of arginine analogs. 


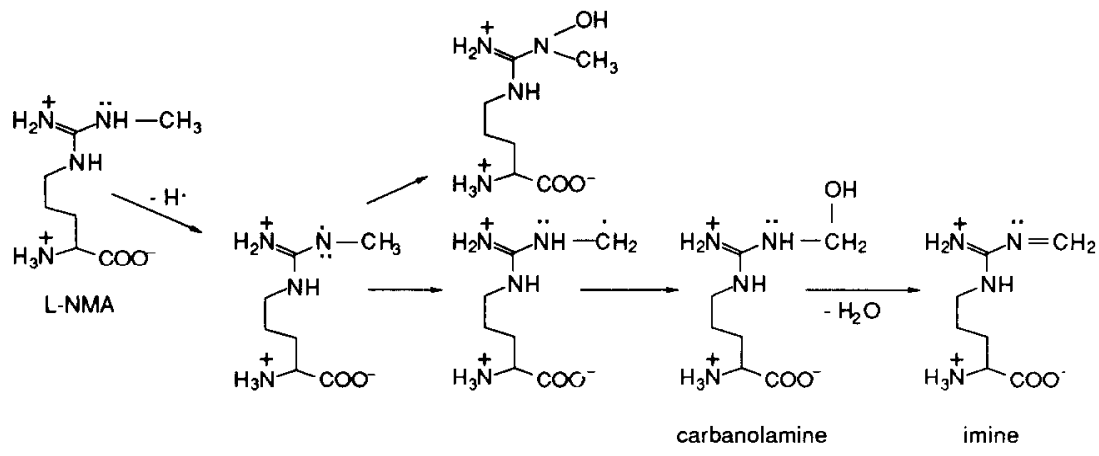

Scheme 1. Two Mechanisms for Inactivation of $\cdot \mathbf{N}=\mathbf{O}$ Synthase by L-NMA.

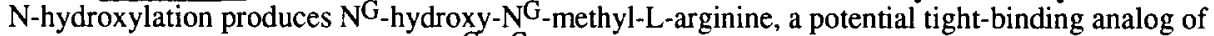

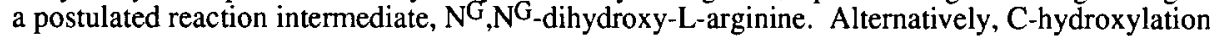
produces a carbanolamine which dehydrates to yield a Michael acceptor imine-like moiety. This, in turn, could hydrolyze to yield formaldehyde and L-arginine.

\section{Acknowledgments}

The studies reported here were supported by NIH grant CA 50414, T32 GM07767 (NMO and KMR) and T32 GM 07863 (MKR). A special thanks to Joanie Hevel for critical comments on this manuscript.

\section{References}

1. Marletta, M.A. (1989) TIBS, 14, 488-492.

2. Bredt, D.S. and Snyder, S.H. (1990) Proc. Natl. Acad. Sci. USA, 87, 682-685.

3. Palmer, M.J.R., Rees, D.D., Ashton, D.S. and Moncada, S. (1988) Biochem. Biophys. Res. Commun. 153, 1251-1256.

4. Yui, Y., Hattori, R., Kosuga, K., Eizawa, H., Hiki, K., Ohkawa, S., Ohnishi, K., Terao, S. and Kawai, C. (1991) J. Biol. Chem. 266, 3369-3371.

5. Tayeh, M.A. and Marletta, M.A. (1991) FASEB J., 5, A787.

6. Marletta, M.A., Tayeh, M.A. and Hevel, J.M. (1990) Biofactors, 2, 219-225.

7. Tayeh, M.A. and Marletta, M.A. (1989) J. Biol. Chem., 264, 19654-19658.

8. Kwon, N.S., Nathan, C.F. and Stuehr, D.J. (1989) J. Biol. Chem., 264, 20496-20501.

9. Stuehr, D.J. and Marletta, M.A. (1987) Cancer Res., 47, 5590-5594.

10. Hibbs, J.B., Taintor, R.R., Vavrin, Z. and Rachlin, E.M. (1988) Biochem. Biophys. Res. Commun.,157, 87-94.

11. Lepoivre, M., Chenais, B., Yapo, A., Lemaire, G., Thelander, L. and Tenu J.P. (1990) J. Biol. Chem., 265, 14143-14149.

12. Green, S.J., Meltzer, M.S., Hibbs J.B. and Nacy, C.A. (1990) J. Immunol. 144, 278-283.

13. Adams, L.A., Hibbs, J.H., Taintor, R.R. and Krahenbuhl, J.L. (1990) J. Immunol., 144, 2725-2729.

14. Hibbs, J.B., Taintor, R.R. and Vavrin, Z. (1987) Science, 235, 473-476.

15. Lambert, L.E., Whitten, J.P., Baron, B.M., Cheng, H.C., Doherty, N.S. and McDonald, I.A. (1991) Life Sciences, 48, 69-75.

16. Gross, S.S., Stuehr, D.S., Aisaka, K., Jaffe, E.A., Levi, R. and Griffith, O.W. (1990) Biochem. Biophys. Res. Commun., 170, 96-103.

17. Feelish, M. and Noack, E.A. (1987) Eur. J. Pharmacol., 139, 19-30.

18. Doyle, M.P. and Hoekstra, J.W. (1981) J. Inorg. Biochem., 14, 351-358.

19. Bradford, M.M. (1976) Anal. Biochem., 72, 248-254.

20. Kitz, R. and Wilson, I.B. (1962) J. Biol. Chem., 237, 3245-3249.

21. Marletta, M.A., Yoon, P.S., Iyengar, R., Leaf, C.D. and Wishnok, J.S. (1988) Biochemisty, 27, 8706-8711.

22. Kaufman, S. (1961) Biochem. Biophys. Acta, 51, 619-621. 